\title{
UTILIZATION OF EDUCATION MANAGEMENT INFORMATION SYSTEM (EMIS) AS AN ANTI- CORRUPTION EFFORT IN MADRASAS
}

\author{
${ }^{1}$ Alfita Choirun Amalia, ${ }^{2}$ Luluk Wulandari, ${ }^{3}$ Evi Fatimatur Rusydiyah \\ ${ }^{1}$ Islamic Educational Management Department, Universitas Islam Negeri Sunan Ampel, \\ Surabaya, East Java, Indonesia \\ ${ }^{2}$ Mathematics Education Department, Universitas Negeri Surabaya, East Java, Indonesia \\ Email : fitacho17@gmail.com¹, lulukwulandari618@gmail.com², evifatimatur@uinsby.ac.id ${ }^{3}$
}

DOI: http:// doi.org/10.33650/al-tanzim.v5i2.2521

\begin{tabular}{l|l|l} 
Received: July 2021 & Accepted: August 2021 & Published: August 2021
\end{tabular}

\begin{abstract}
:
This study aims to determine the use of the Education Management Information System (EMIS) within the Madrasah to implement anti-corruption education. This research belongs to the type of descriptive qualitative research by describing the facts or findings in the field. The data collection technique is done through interviews, observation methods, and documentation. The instrument used in this research is the instrument using a questionnaire. The results show that the use of the education management system (EMIS) as the implementation of anti-corruption education is quite effective because the distribution of Education Operational Costs (BOP) to madrasas no longer has to pass through various parties but is directly channeled through school accounts, so there are no more deductions in the distribution process. The use of EMIS is also inseparable from internal and external constraints. From the inner aspect, it includes human resources who do not understand EMIS operations. Meanwhile, external factors include the EMIS central server, which requires further improvement to comfort and convenience for madrasas.
\end{abstract}

Keywords: Education Management Information System (EMIS), Anti-corruption, Madrasas

\begin{abstract}
Abstrak:
Penelitian ini bertujuan untuk mengetahui pemanfaatan Education Management Information System (EMIS) dalam lingkup Madrasah sebagai implementasi pendidikan antikorupsi. Penelitian ini termasuk jenis penelitian kualitatif deskriptif dengan menguraikan secara apa adanya fakta atau temuan di lapangan. Teknik pengumpulan datanya dilakukan melalui wawancara, metode observasi, dan dokumentasi. Instrumen yang digunakan dalam penelitian ini yakni instrumen menggunakan kuesioner. Hasil penelitian menunjukkan bahwa penggunaan education management system (EMIS) sebagai implementasi pendidikan antikorupsi cukup efektif, karena penyaluran Biaya Operasional Pendidikan (BOP) kepada madrasah tidak lagi harus melewati berbagai pihak, akan tetapi langsung disalurkan melalui rekening sekolah, sehingga tidak ada lagi pemotongan di dalam proses distribusi. Penggunaan EMIS juga tidak lepas dari kendala internal maupun eksternal. Dari aspek internal meliputi sumber daya manusia yang belum memahami operasional EMIS. Sedangkan faktor eksternal meliputi server pusat EMIS yang memerlukan perbaikan lebih lanjut agar dapat memberikan kenyamanan dan kemudahan bagi madrasah.
\end{abstract}

Kata Kunci: Education Management Information System (EMIS), Antikorupsi, Madrasah 


\section{INTRODUCTION}

The modernization and development of information and communication technology (ICT) have brought significant changes in human life systems from various sectors, including the education sector. For example, there is a revolution from "traditional" education to "modern" education both in the learning process and management (Aziz, 2014).

In terms of education management, the use of information technologybased management is essential so that the policies taken can be by the needs in a precise and accurate manner (Sholeh, 2017). Alignment between conditions and procedures issued by management will bring education to achieve the goals (Maula, 2020).

Arguably, the successful adoption of any system is determined by users' acceptance rather than by its supposedly sophisticated features. In other words, users must be satisfied when they use such a system. Otherwise, the system would be deemed irrelevant. In this regard, it is essential to understand why a particular technology will be accepted or rejected by users.

The Directorate of Madrasah and Religious Education (Mapenda), as one of the institutions under the Ministry of Religious Affairs, is responsible for implementing religious education. Madrasas and schools have used the Education Management Information System, known as EMIS, equipped with the information needed for decision-making in the field of education (Rahmania et al., 2020). This system records the number of institutions, educators, education personnel, facilities owned, and others. With this system, it is hoped that the data can be more accurate and continuously updated to be used as a basis for policymaking and transparent accountability (Fakrulloh, 2011).

In some places, the distribution of BOP from the Central Government to madrasas did not match the nominal stated at the beginning because the BOP was cut when it went through several parties. Thus, the nominal received by the madrasa is far from the nominal indicated at the beginning. In addition, misuse of EMIS data also occurs in budgeting by including the number of students who do not match the actual conditions in the field, so that it will be detrimental to the state. These two phenomena are only a few of the problems in the EMIS system. Whether EMIS is right on target in tackling planning and budgeting problems in the madrasah scope, this is so that transparency in planning, budgeting, and distribution of BOP can be achieved.

According to the Secretary of the Directorate General of Islamic Education, in data validation and verification activities for madrasas and Islamic religious education in Batam, the importance of EMIS data is divided into two aspects, namely the planning aspect and the budget absorption aspect. "Planning without data is like a dream in broad daylight; without data, Islamic education programs are empty." He added, "Valid data leads to solid planning so that budgeting is accurate. The sequence is obvious. Budgeting is correct, appropriate, not excessive, and not lacking. This will give birth to true accountability" (Sukman, 2020). 
Corruption is the misuse of state money (companies, organizations, foundations, etc.) for personal or group interests. Corruption has become a global problem because it harms public trust, social institutions and damages the environment (Syafira, 2015). In Indonesia, there is Law No. 31 of 1999 concerning the Eradication of Corruption, that corruption is very detrimental to state finances or the state economy and hinders national development (Subkhan, 2020). In addition to harming state finances or the state economy, corruption also impedes the growth and continuity of national development, demanding high efficiency (Aziz, 2014). Therefore, the eradication of corruption must be carried out extraordinarily.

The impact is massive, so that corruption is categorized as an extraordinary crime (extraordinary crime) equivalent to mass murder (Pertiwi, 2019). Actions included in corruption can be seen in Law No. 31 of 1999 concerning the eradication of corruption (Wijaya, 2016). In this article, there are 30 forms or types of corruption. Still, in this study, these thirty forms or types of corruption are simplified into seven major groups: state financial losses, bribery, embezzlement in office, extortion, fraudulent acts, conflict interest in procurement, and gratuities.

According to Pertiwi (2019), corruption is caused by habitus regulating ways of thinking without awareness and can occur due to pressure from external factors, expectations attached to individuals. Not much different, Yamamah revealed that corrupt behavior occurs due to external and internal elements of the perpetrators. Corruption occurs because of the wasteful and materialistic attitude to dominate individuals and the government system encouraging corruption (Kuding \& Irwansyah, 2020).

Corruption is a complex issue, not only its impact, but it is also very thick with moral degradation as a form of the inability of a social actor to choose moral or ethical behavior due to misunderstanding or defective morality (Amin et al., 2018).

Based on the background above, this study aimed to discover the utilization of the Education Management Information System (EMIS) in madrasas as an anti-corruption effort. After knowing the urgency of using EMIS (Education Management Information) in budget absorption, the truth can then be justified and avoid misuse of data from budget manipulation to implement anti-corruption efforts in madrasas to create a positive and healthy climate within the scope of education.

Studies discussing the issue of Education Management Information System-Based Policy Making (EMIS) have been carried out, such as a study by Sina and Mahsyar, "Implementation of Education Management Information System (EMIS) in Religious Education Institutions and Islamic Boarding Schools at Makassar City Religious Affairs Office" which discusses the implementation of EMIS in policymaking in Madrasah Diniyah and Pesantren focusing on four components namely human resources, work tools, and software. This kind of study was also found in a survey by Rahmania, Agus Ainul Yakin, and Elvira Rohadatul Aisy, "Optimizing EMIS in the Database Process for Madrasah Diniyah and Pesantren in Bangkalan Regency Religious Affairs Office" that the 
use of Madrasah Diniyah and Pesantren is not optimal because human resource who do not fully understand EMIS.

This study focused more on the function of EMIS in planning and budget absorption and anti-corruption efforts in madrasas. This study reviewed the role of EMIS in the transparency of BOP planning, budgeting, and distribution in madrasas.

\section{RESEARCH METHODS}

This qualitative descriptive study described the facts or findings of EMIS utilization in madrasas (Raharjo, 2012). The subjects of this study were school principals, EMIS data managers, and school treasurers. The samples were taken from Madrasah Aliyah Darul Ulum Waru Sidoarjo. This madrasa is one of the oldest Madrasah Aliyah in the Sidoarjo Regency area, with the highest number of students ( \pm 1200 students). Several methods were used to obtain valid and focused data, such as interviews, observation, and documentation. This study used a questionnaire as an instrument to be analyzed in four stages, namely collecting, presenting, analyzing, and concluding (Fakrulloh, 2011).

This study used a questionnaire as an instrument applied in a google form, making it easier for respondents and researchers to provide and obtain data. This study used three indicators to measure EMIS. The first aspect is the general essential knowledge aspect, including basic knowledge, data collection procedures, principles, and EMIS functions. The second aspect is governance, including an understanding of governance and knowledge of operating an EMIS. The third aspect is EMIS data, including forms of EMIS data misuse, optimization of EMIS in planning, budgeting, and accountability, as well as steps to prevent misuse of EMIS data as an anti-corruption effort in madrasas.

\section{RESULTS AND DISCUSSION \\ Graph of Questionnaire Results}

The questionnaire distribution was used to collect observational data on the utilization of the Education Management Information System (EMIS) in madrasas as an anti-corruption effort

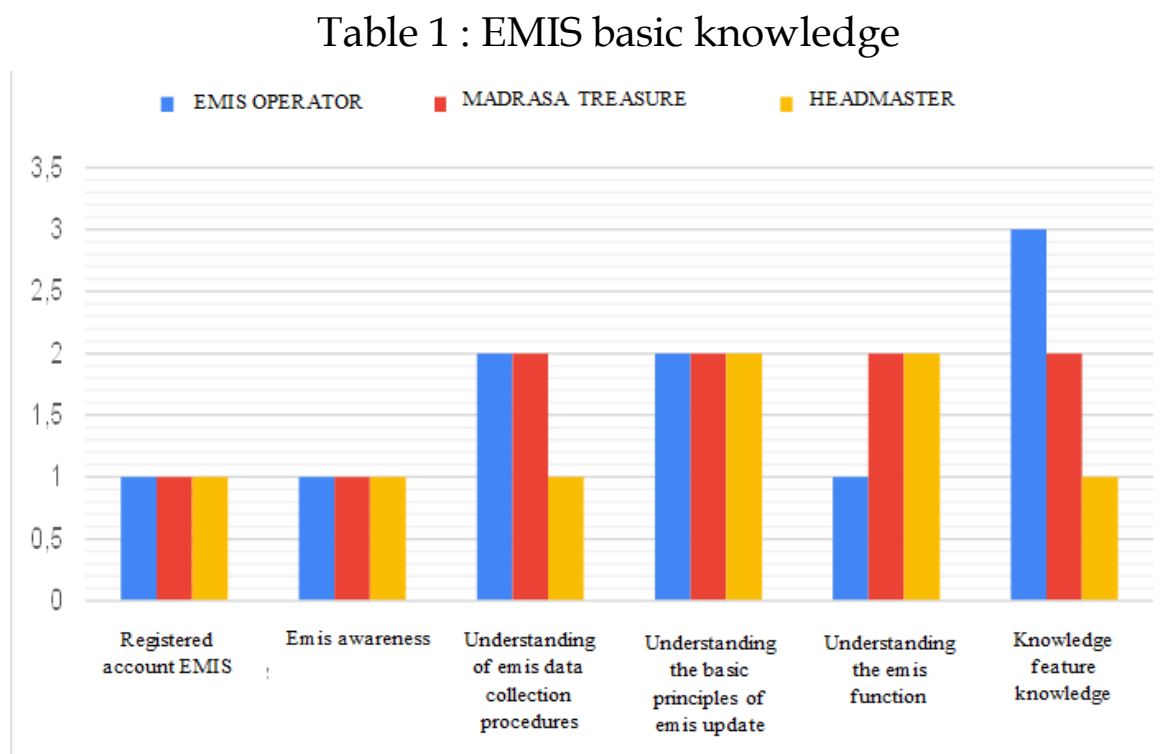




\section{Tabel 2 : Understand EMIS application governance}

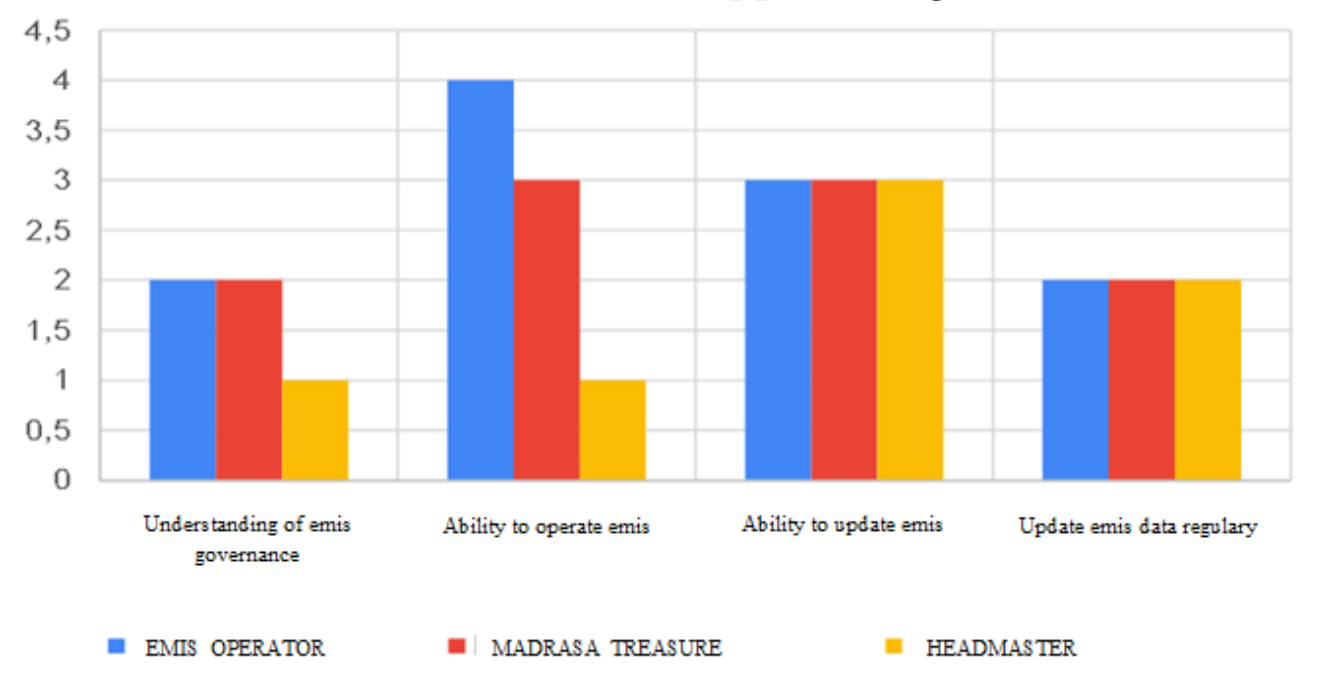

Based on Table 1, basic knowledge about EMIS tends to be the same. The questionnaire results show that the average score was two, meaning that basic knowledge about EMIS among stakeholders was low to medium. Based on Table 2, the questionnaire results are more diverse. The score of the principal was lower because, according to him, "all tasks have been divided according to expertise, the principal is only as a supervisor and controller of team performance so that everything can be well-coordinated".

Tabel 3 : Utilization of EMIS as an anti-corruption effort

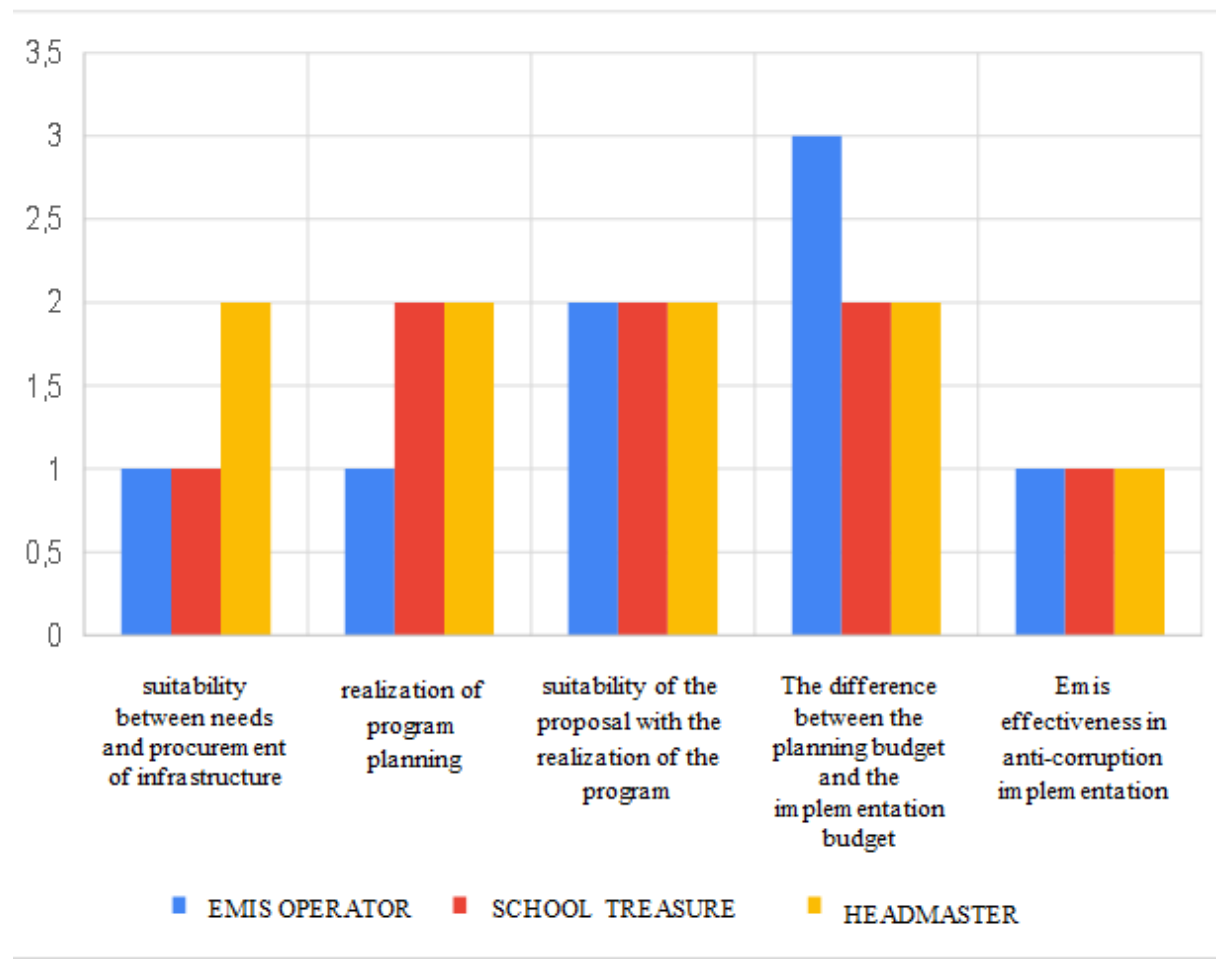


Table 3 shows relatively stable results with an average score of 2 . Coordination between teams at MA Darul Ulum makes the process of planning, budgeting, and updating EMIS run continuously. The difference between the planning and implementation budgets is not too conspicuous because the budget provided is adjusted to the procurement needs and the number of students included in the emission data. Therefore, the distribution of BOP funds is stringent. Both from educational institutions and from madrasah, BOP providers are required to meet the requirements set in disbursing funds.

The questionnaire results show stakeholder involvement in updating EMIS data because it will affect the effectiveness of EMIS in the data processing. In the BOP disbursement process, planning and budget proposals are needed according to the number of students so that the needs of these students can be met. Planning proposals submitted for BOP disbursement do not always match the realization results due to changing conditions and student data, but this is not a problem if the difference is not too far apart. "This is fair," according to the principal of MA Darul Ulum when interviewed. Problems arise if the planning proposal has a significant difference, especially not by the proposed budget.

This study focused on the utilization of EMIS as an anti-corruption effort on conflicts of interest and procurement. According to the principal of MA Darul Ulum, EMIS as a database is considered effective in planning and budgeting because the BOP given is by the proposal submitted so that the nominal is adjusted to the number of students.

The Holocaust of corruption is carried out with two approaches, namely prevention and prosecution. Through this prevention approach, the role of various parties is needed (Sugiono, 2018). Prevention of corruption can be performed by strengthening internal factors so that individuals are not tempted to sin. Instilling the values of integrity and monotheism is always carried out in every meeting with various elements of the madrasa unit (Abdurahman, 2017). One of the causes of corruption is low self-integrity. The low self-integrity is also a sign of a low level of faith in God because someone does not believe that everything happens by God's will so that someone dedicates interests and material things, which then gives rise to greed (Kuding \& Irwansyah, 2020). The MA Darul Ulum school said; The sanctity of property is essential for children; knowledge can enter children if the treasure is sacred. We do not only focus on the intellectual intelligence of students but also pay attention to emotional intelligence so that later it can bring blessings in learning as well as soul sanctity.

Thus, the utilization of EMIS as an anti-corruption effort in MA Darul Ulum so far can be said to be quite capable of tackling corruption by strengthening the internal factors of madrasas and instilling integrity, which if these students receive sources of funds for learning needs that are not sourced, or through an incorrect process, it will reduce the usefulness of knowledge (Bashori, 2019). This is also supported by external factors where financial assistance from the Ministry of Religious Affairs goes directly to school accounts and no longer passes through various parties. The amount received for the school is intact by the budget. 
The use of the education management system (EMIS) cannot be separated from constraints such as lack of facilities and skilled staff or even data manipulation errors that can affect data quality (Aziz, 2014). MA Darul Ulum does not encounter difficulties in planning, budgeting, or updating EMIS because the organization within the madrasa has been divided according to their respective fields, skills, and expertise and always maintaining cooperation and coordination between teams. According to the Principal of MA Darul Ulum; "Here we have divided our respective fields of work, for data collection, there is a special team that takes care of all school data needs such as completeness of student personal data (original school certificate, NISN, number of transfer students, etc.) or to update EMIS data, while for program planning the IT team coordinates with the school treasurer, principal, and related parties as a preventive measure to involve various parties in the planning and budgeting process".

However, there are also obstacles, such as; 1) incomplete student data due to the certificates being held at the original school, so they have to wait for it to be complete, the changing data for new students, and transfer students in the middle of the semester so that the update process cannot be carried out automatically; 2) The operation of the EMIS application is hampered because the server is often in trouble, so the process of updating student data needs to be scheduled. Therefore, it is hoped that the Ministry of Religious Affairs can improve the quality of the EMIS application as a form of better service.

\section{CONCLUSION}

Funds and finance are vital for individuals, groups, and institutions. Planning, budgeting, and distribution must be appropriately managed; therefore, a reliable system is needed to produce sound, effective, efficient, transparent, and accountable planning to achieve integrity in madrasas.

The utilization of EMIS as an anti-corruption effort in MA Darul Ulum so far can be said to be quite capable of tackling corruption by strengthening the internal factors of madrasas and instilling integrity. This is also supported by external factors where financial assistance from the Ministry of Religious Affairs goes directly to school accounts and no longer passes through various parties. The amount received for the school is intact by the budget. The utilization of the education management information system (EMIS) has problems such as poor quality of EMIS application. Also, it delays data collection due to administration with the school of origin.

This study is undoubtedly far from perfect in terms of management, fund development, or institutional finance. Further studies are recommended to target the optimization of EMIS with the principle of health management as an anti-corruption implication to accommodate funds or institutional finances and process EMIS data coherently. 


\section{REFERENCES}

Abdurahman, A. (2017). Pengembangan Desain dan Pendekatan Perencanaan (Planning) dalam Manajemen Pendidikan Islam. Al-Tanzim: Jurnal Manajemen Pendidikan Islam, 1(2), 15-24. https://doi.org/10.33650/altanzim.v1i2.110

Amin, N., Siswanto, F., \& Hakim, L. (2018). Membangun Budaya Mutu yang Unggul dalam Organisasi lembaga Pendidikan Islam. Al-Tanzim: Jurnal Manajemen Pendidikan Islam, 2(1), 94-106. https://doi.org/10.33650/altanzim.v2i1.308

Aziz, F. (2014). Pengambilan Kebijakan Berbasis Education Management Information System (EMIS). Jurnal Pendidikan Islam, 3(1), 135-162. https:/ / doi.org/10.14421/jpi.2014.31.135-162

Bashori, B. (2019). Kepemimpinan Transformasional Kyai pada Lembaga Pendidikan Islam. Al-Tanzim: Jurnal Manajemen Pendidikan Islam, 3(2), 7384. https:// doi.org/10.33650/al-tanzim.v3i2.535

Fakrulloh, Z. A. (2011). Akuntabilitas Kebijakan dan Pembudayaan Perilaku AntikorupsI. Perspektif, 16(2), 105-116.

Kuding, I. M., \& Irwansyah, I. (2020). Pemanfaatan Ragam Aplikasi Seluler Antikorupsi dalam Upaya Pencegahan Korupsi. Jurnal Komunikasi, 12(2), 263-281. https://doi.org/10.24912/jk.v12i2.8626

Maula, L. H. (2020). Analisis Kesulitan Pengelola Lembaga Pendidikan dalam Pelaksanaan Emis. Jurnal Elementaria Edukasia, 3(2), 1-11. https://doi.org/10.31949/jee.v3i2.2501

Pertiwi, K. (2019). Kesenjangan dalam Wacana Antikorupsi di Indonesia: Temuan dari Literatur Studi Korupsi Kritis. Integritas : Jurnal Antikorupsi, 5(2), 133-150. https://doi.org/10.32697/integritas.v5i2.475

Raharjo, S. B. (2012). Evaluasi Trend Kualitas Pendidikan di Indonesia. Jurnal Penelitian dan Evaluasi Pendidikan, 16(2), 511-532. https://doi.org/10.21831/pep.v16i2.1129

Rahmania, S., Yakin, A. A., \& Aisy, E. R. (2020). Optimalisasi Emis dalam Proses Data Base Pendidikan Diniyah dan Pondok Pesantren di Kementerin Agama Kabupaten Bangkalan. Jurnal Administrasi Pendidikan Islam, 2(1), 17-31. https://doi.org/10.15642/japi.2020.2.1.17-31

Rofiq, A. (2017). Wealth Management Strategi Pengelolaan Asset:Transparansi, Akuntabilitas, Efektifitas, Efisiensi. Al-Tanzim: Jurnal Manajemen Pendidikan Islam, 1(1), 64-75. https://doi.org/10.33650/al-tanzim.v1i1.28

Sholeh, M. (2017). Kajian Kritis Tentang Standar Nasional Pendidikan (SNP). Al-Tanzim: Jurnal Manajemen Pendidikan Islam, 1(1), 36-55. https://doi.org/10.33650/al-tanzim.v1i1.26

Subkhan, E. (2020). Pendidikan Antikorupsi Perspektif Pedagogi Kritis. Integritas: Jurnal Antikorupsi, 6(1), 15-30. https:// doi.org/10.32697/integritas.v6i1.649

Sugiono, S. (2018). Strategic Planning: Shaping or Emerging from Organisations. Al-Tanzim: Jurnal Manajemen Pendidikan Islam, 2(2), 177184. https:/ / doi.org/10.33650/al-tanzim.v2i2.399 
Sukman. (2020). Peningkatan Kemampuan Guru PAI dalam Update Data Emis Oline Melalui BIMTEK Pada MGMP SMK Kabupaten Lombok Barat. Jurnal Penelitian Keislaman, 16(2), 103-116. https:// doi.org/10.20414/jpk.v16i2.2437

Wijaya, A. (2016). Pemberantasan Tindak Pidana Korupsi Menurut UU No. 31 Tahun 1999 Jo. UU No. 20 Tahun 2001. Al-Jinayah: Jurnal Hukum Pidana Islam, 2(1), 178-209. https:/ / doi.org/10.15642/aj.2016.2.1.178-209 